\title{
Financial Market Integration of ASEAN-5 with China
}

\author{
Rui Dias ${ }^{1}$, Pedro Pardal ${ }^{1}$, Nuno Teixeira ${ }^{1}$, Veronika Machová ${ }^{2}$ \\ ${ }^{1}$ Polytechnic Institute of Setúbal, School of Business and Administration, Portugal \\ 2Institute of Technology and Business in České Budějovice, School of Expertness and \\ Valuation, Czech Republic
}

\begin{abstract}
This study aims to estimate the potential portfolio diversification in the financial markets of Indonesia, Malaysia, Philippines, Singapore and Thailand (ASEAN-5), and of China, in the context of China stock market crash, in 2015. For this purpose, we establish two research questions: i) China stock market crash promoted financial integration between the ASEAN-5 and China markets? ii) if so, does this effect had a positively influence in the occurrence of short-term co-movements between markets? Using stock market data from January 2015 to January 2019, we found that, during the crash, the level of financial integration rose 533\%, which supports our first research question. However, during the 2015 stock market crash, most markets decreased the co-movements with their regional peers, which does not corroborate the second assumption. Additionally, analysis to the relationship between the markets, through the impulse response function showed evidence of positive comovements, with statistical significance and persistence longer than one week. Thus, the ASEAN-5 and China markets may not be efficient in their weak form, since there was no immediate adjustment in prices between markets, due to the high levels of market shocks identified. However, we believe that the implementation of efficient portfolio diversification strategies, based on historical prices, remains beneficial for investors.
\end{abstract}

Keywords: financial integration, co-movements, ASEAN-5, portfolio diversification

\section{Introduction}

The Chinese financial market has expanded exponentially since the creation of the Shanghai and Shenzhen Stock Exchanges in the 1990s. At the end of 2014, the market 
capitalization of the two stock exchanges was equivalent to $58.53 \%$ of the country's GDP, according to the Annual Report of China Security Regulatory Commission (2014). In order to liberalize local markets, the Chinese government introduced two categories of shares, namely shares $A$ and $B$, defined according to their rating. The dual listing nature of the Chinese stock market has resulted in a partially segmented financial market, although the government has taken several steps to liberalize China's financial operations. After joining the World Trade Organization (WTO) in 2001, several financial liberalization measures were taken by the Chinese authority to open the financial market and improve financial regulations, to Qualified Domestic Institutional Investors and Qualified Foreign Institutional Investors. The implementation of these reforms has led to a gradual easing of restrictions on domestic and international investors and has further encouraged international financial integration. These selective reforms in the financial markets were aimed at promoting the process of "globalization" of Chinese stock exchanges. As a result, we see China increasingly playing a leading role and increasing its influence in the global financial markets (Jakpar et al., 2013; Teng et al., 2014; Chien et al., 2015; Ahmed and Huo, 2019).

Despite these positive developments, the Chinese stock market suffered the most severe crash in the post global financial crisis (GFC). The stock market turmoil began in June 2015 after a sharp slowdown in Chinese economic growth and ended in late January 2016. The unexpected devaluation of the Chinese currency (RMB) and the weakening outlook for future GDP growth, in China, may have been important contributions to this fall. After weeks of volatility and swings in stock prices, the Shanghai composite index lost about $25 \%$ of its value in one month, the index dropped from 5,178 to 2,850 on June 12, 2015. Particularly on Monday, August 24, 2015, the Shanghai stock market saw a sharp drop of $8.5 \%$ and on Tuesday, August 25, 2015, shares fell a further $7.6 \%$. These two days of sharp decline had a major impact on the Chinese economy. The observed financial turmoil spread to other regional stock markets, currencies and commodities. As a result, the Dow Jones Industrial Average fell about 1,000 points on Monday, August 24, 2015. In January 2016, China's stock market fell about $25 \%$. In particular, on January 4 and 7,2016 , trading in the stock market was interrupted, after a 7\% drop, which led to the suspension of trading (Salidjanova and Koch-Weser, 2015).

Thus, the main objective of this investigation is to estimate potential portfolio diversification in the financial markets of Indonesia, Malaysia, Philippines, Singapore and Thailand (ASEAN-5), and the market of China, in the context of the stock market crash in the latter country in 2015. For this purpose, two research questions were established: $i)$ China stock market crash promoted financial integration between the ASEAN-5 and China markets? ii) If so, does this effect had a positively influence in the occurrence of short-term co-movements between markets?

This research adds two relevant contributions to the literature. First, it explores financial integration in ASEAN-5 and China stock markets in the context of China stock market crash in 2015, including the different predictability between them. Following the Asian financial crisis, China and ASEAN-5 are showing a significant growth on the international 
economic scene, which has highlighted the importance of analyzing the level of integration between these markets. To this purpose, several studies analyzed the integration of stock markets in ASEAN (Chen et al., 2009; Lim, 2009; Shabri Abd Majid et al., 2009), the synchronizations between China and other financial markets (Burdekin and Siklos, 2012; Lean and Teng, 2013; Teng et al., 2016), and the links between ASEAN-5 and Japan or the United States (Azman-Saini et al., 2002; Ibrahim, 2006; Majid, Meera and Omar, 2008; Rahman, Othman and Shahari, 2017; Rijanto, 2017). However, few studies have analyzed the relationship between China's stock markets and ASEAN-5. Thus, we try to respond to this literature gap by studying the synchronizations between these Asian markets, in the context of the 2015 stock market crash.

The second contribution is related to the growing importance of the ASEAN-5 markets. According to Lim (2009), ASEAN is the fourth largest trading region in the world, with ASEAN-5 countries representing $72.8 \%$ of the ASEAN population and $95.1 \%$ of its GDP. The average annual economic growth rate of ASEAN has been approximately $5 \%$ over the last two decades (Petri, Plummer and Zhai, 2012). Several comprehensive political and economic reforms were implemented, in the region, during the Asian financial crisis. In addition, the region benefits from political and economic partnerships with China, Japan, the US and the European Union (Chachavalpongpun and Chachavalpongpun, 2018). Indeed, China's recent economic growth and the signing of the Free Trade Agreement with ASEAN for the development of a single market has increased economic integration between China and ASEAN. The preference for these ASEAN-5 financial markets is explained by their unstable and rapidly developing economies, which are therefore linked by a cultural heritage and similar economic conditions. In addition, these markets have become an important investment destination, after the recent financial crisis in 2008. In this context and due to the large capital flows, it is of great importance to understand the interdependencies and links between these regional financial markets.

\section{Literature Review}

Since the mid-2000s, international financial markets have been subject to a number of significant financial crises, as the subprime crisis in the US in 2008 and the sovereign debt crisis in Europe in 2010, originated in developed economies. These events significantly affected developed economies, but significance was not accentuated in emerging economies (Wong and Li, 2010). Coeurdacier and Guibaud (2011) analyzed whether investors correctly protect portfolios from domestic risk by investing in international stock markets that have low correlation with their domestic stock market. The authors suggest that investors move their investments to foreign markets, which offer better opportunities for diversification. Understanding the international links between stock markets and research on the occurrence of financial integration and co-movements phenomena, in the context of stock market crashes, is important for investors, investment fund managers and academics in several aspects, namely portfolio diversification in an international context (Dias, da Silva and Dionísio, 2019). From the investor's point of 
view, knowledge of the form and intensity of interdependence between the different financial markets is vital for efficient hedging decisions, in order to minimize the adverse effect of uncertainty on expected returns. Similarly, an understanding of the interdependence relationships between international stock markets facilitates the identification of opportunities for diversification (Pownall, Satchell and Srivastava, 2019).

McKinnon and Schnabl (2003) and Forbes and Rigobon (2002) found that China played a stabilizing role in the Asian region, during the 1997 Asian financial crisis, since its economy was not affected. The possibility of external financial turbulence influencing China's stock market was relatively low, because its stock market was still isolated from the rest of the world (Yu, Fung and Tam, 2010; Huyghebaert and Wang, 2010). This is also supported by the results of Azad (2009) and of Caporale et al. (2013). Both showed that the volatility spillover from mature markets (US and Japan) to emerging markets (China) did not result in significant contagion. In addition, the Chinese stock market shows some predictability Azad (2009). Therefore, it is beneficial for international investors to diversify their portfolios into this market. However, this recommendation is only effective during tranquility periods in China, but not in periods of financial turbulence as demonstrated by Wang, Chen and Huang (2011).

More recently, Glick and Hutchison (2013), Auer and Mehrotra (2014), Boubakri and Guillaumin (2015), Pradhan et al. (2016), Wu (2019), Gulzar et al. (2019) examined the synchronizations between China's market and Asia's financial markets, and how these links changed during and after the 2008-2009 global financial crisis. Glick and Hutchison (2013) show little synchronization between long-term interest rates, but the financial integration between stock markets is very significant. This conclusion is consistent with the further development and liberalization of stock markets relative to the securities markets in China, as well as with the increase in trade links in the region. Auer and Mehrotra (2014) argue that increased integration has led to greater co-movement among asset prices. The authors point out that real integration, through the supply chain, is important for domestic prices dynamics in the Asia-Pacific region. Boubakri and Guillaumin (2015) show that East Asian stock markets were partially segmented (except Japan) in the region until 2008. However, the recent years are characterized by an upward trend in the regional integration of these stock markets. Pradhan et al. (2016) used a multivariate structure, showing that all variables are co-integrated and revealing a network of causal connections, including short-term bidirectional causality between market penetration and economic growth. Wu (2019) argues that a large part of this evident high level of integration is demonstrated by common global factors. After filtering out these factors in each stock market, the magnitude of integration decreases substantially. Thus, the results suggest that stock market integration in East and Southeast Asia is not as strong as it appears, despite the regional governments are promoting collaboration and financial integration in these markets. Gulzar et al. (2019) examined Asian financial markets (India, China, Pakistan, Malaysia, Russia and Korea) and the US. The analysis included daily stock returns from July 1, 2005 to June 30, 2015, with 
the sample divided into three periods. The results show long-term cointegration between the US market and emerging stock markets, and the level increased after the crisis period.

\section{Methods and Data}

To respond to our research questions, we used the daily index quotations of ASEAN-5 and China (Shanghai) stock markets, taken from Thomson Reuters database. We used local currency quotations in order to mitigate exchange rate distortions. Daily quotations comprise the period from January 5, 2015 to January 31, 2019.

In addition, and in order to highlight the impact of the Shanghai (China) stock market crash on the evolution of the different markets, the sample was divided into three subperiods. The pre-crash subperiod from 5 January 2015 to 11 June 2015, the crisis subperiod, which represents the stock market crash and goes from 12 June 2015 to 30 January 2016, and a third subperiod from 1 February 2016 to 31 January 2019, which we call the post-crash subperiod (Ahmed and Huo, 2019). The table 1 provides an overview of the countries and their indices.

Tab. 1: Sample - Countries and their indices

\begin{tabular}{|l|r|}
\hline \multicolumn{1}{|c|}{ Country / Region } & Indices \\
\hline INDONESIA / ASEAN-5 & Jakarta Stock Exchange Composite Index \\
\hline MALAYSIA / ASEAN-5 & FTSE Bursa Malaysia Index \\
\hline PHILIPPINES / ASEAN-5 & Philippines Stock Exchange PSEi Index \\
\hline SINGAPORE / ASEAN-5 & Singapore Exchange - SGX \\
\hline THAILAND / ASEAN-5 & Stock Exchange of Thailand \\
\hline CHINA / ASIA & Shanghai Stock Exchange Composite Index \\
\hline
\end{tabular}

Source: Authors.

Research methodology is carried out through several stages, starting with the samples' characterization using descriptive statistics and the adherence test (Jarque and Bera, 1980 ) in order to show the values of the means, standard deviations, asymmetry and kurtosis of the financial market indices analyzed. Then, we perform an evaluation to the stationarity of the time series, in order to check if the variance of financial market prices was stable over the period in study. Third, we proceed to the identification of possible structural breaks of the time series in order to estimate the most adequate integration model. Finally, we analyze the level of integration or segmentation of all the stock market indices in test and then proceed to the evaluation of shocks (co-movements) between the stock markets in crash and both non-crash subperiods.

To evaluate time series stationarity of all ASEAN-5 and China markets we will use the ADF, PP and KPSS tests. Following to the analysis of the data series, we will use the Clemente, Montañés and Reyes (1998) test to assess the existence or not of structural breaks in the six financial markets.

The decision to employ tests with null opposite hypotheses is to mitigate the fact that the ADF tests (Dickey and Fuller, 1981), PP (Phillips and Perron, 1988) and KPSS 
(Kwiatkowski et al., 1992) have low power when compared with econometric methodologies that postulate structural breaks (Maddala and Kim, 1998). Complementarily, Noman and Rahman (2010), when examining stationarity of time series-data, support the idea that results of linear unit root tests (such as ADF, PP and KPSS) can lead to biased results when used in time series that present structural breaks.

As previously mentioned, in addition to the ADF, PP and KPSS stationarity tests, we will use methodologies that aim at measuring possible structural breaks, namely the CUSUMQ test of Inclán and Tiao (1994) and the test of Clemente, Montañés and Reyes (1998). These tests allow the identification of possible structural breaks, and in the case of Clemente, Montañés and Reyes (1998), we may identify the year with the most severe breakage. A structural break leads to a significant change in the level and/or trend of a time series, a change, which may be of a stable or transitory nature. If the series is stationary, the shocks should have temporary effects, if not, they will have permanent effects, i.e., they do not recover to the initial level.

The modelling of structural breaks in cointegrated processes has been a widely studied topic in the last years. The reason why standard cointegration tests like Engle and Granger (1987) and Johansen (1988) are not suitable for testing cointegration with regime change (structural breaks), is based in the fact that such tests assume that the cointegration vector is invariant in time.

The cointegration tests with structural break will follow the methodology of Gregory and Hansen (1996). In this study, the authors were concerned with a general test model in which the cointegration vector varies with time. The method developed by Gregory and Hansen (1996) is considered a complement to the ADF test. In addition, it can also be affirmed, from an econometric point of view, as a multivariate version of the Zivot and Andrews (1992) model. According to the authors, the existence of structural breaks may lead to erroneous conclusions regarding the acceptance of the null hypothesis of noncointegration and, therefore, the non-existence of any type of long-term relationship between variables $I(1)$.

In order to analyze whether the co-movements among the five main ASEAN markets are positive or negative, in the context of the China stock market crash, we will use the impulse response function (IRF) methodology, with Monte Carlo simulations. These functions provide a dynamic analysis (variable with time), created from the estimates of the VAR model, making possible to study the calculated causality relationships, even when no previous Granger causality relationships between the variables are detected (Lütkepohl and Saikkonen, 1997).

The impulse-response function shows how a given variable responds over time to an unexpected increase in that variable (stimulus or innovation) or in another variable included in the VAR model. In other words, an innovation in a given variable produces a chain reaction over time in the other variables of the VAR, which the impulse-response function allows to follow and interpret. 


\section{Results}

With regard to the evolution of the financial market indices, figure 1 shows the oscillations, in first differences, of the six financial markets (ASEAN-5 and China). The sample comprises the time horizon from January 5, 2015 to January 31, 2019, being a very complex period, due to the necessity of understanding the effects of stock market crash in China. The analyzed financial market indices clearly reveal the instability experienced in these markets, being more intense in the years 2015-2016. It is also possible to see an "equilibrium" movement in the year 2017, however, the year 2018 suggests an increase in volatility.

Figure 1: Annual first differences in the financial markets from 05/01/2015 to $30 / 01 / 2019$

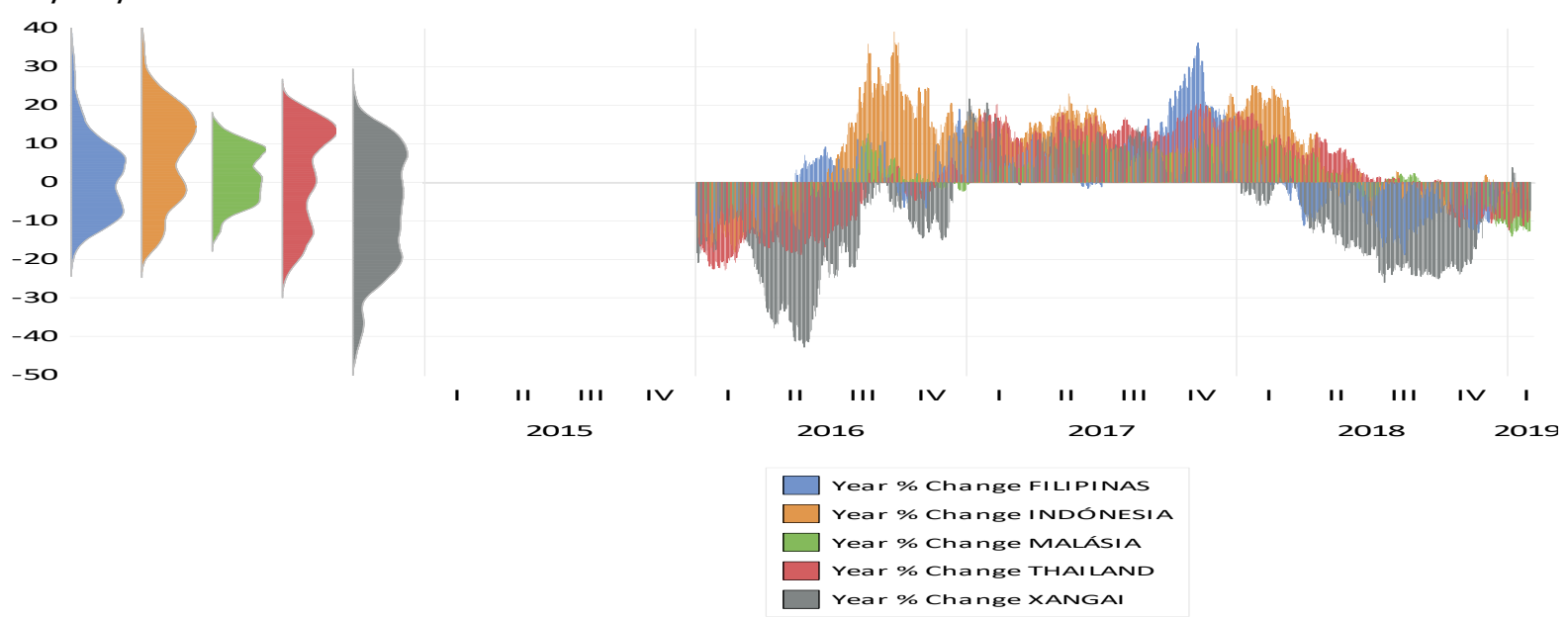

Note: Thomson Reuters: 5 January 2015

Source: Authors.

Descriptive statistics of profitability, in the six financial markets, allow us to assess that Indonesia, Philippines and Thailand show daily positive profitability means. However, in Malaysia, China and Singapore the means are negative. China is the market with the largest standard deviation and the largest kurtosis, which suggests the existence of significant volatility. On the other hand, all series showed signs of deviation from the normality hypothesis, given the asymmetry and kurtosis coefficients. The asymmetry characteristics are negative, with greater emphasis on the Chinese market. Additionally, the asymmetry and kurtosis coefficients are statistically different from those of a normal distribution.

Since we are estimating time series, we should analyze profitability stationary nature in the six financial markets. In the table below, we can observe that the performed ADF tests (Dickey and Fuller, 1981), PP (Phillips and Perron, 1988) and KPSS postulate the same null hypotheses, while the KPSS test (Kwiatkowski et al., 1992) exposes opposite hypotheses. The intersection of the unit root tests shows the stationarity of profitability. 
However, we should highlight the lags in the tests (observed by the differences between the lags that presented in brackets in the various tests), which suggest that the time series may not be stable and. Due to this evidence, we will perform the test of Clemente et al. (1998) which analyses the stationarity with the effect of structural breaks.

In order to confirm the unit root tests, we run the CUSUMQ test of Inclán and Tiao (1994). The determination of structural breakage is relevant, as it has a potentially similar effect to unitary roots. Through the graphical analysis, we can assess whether there are disturbances in variance. Thus, by examining the graphs of the cumulative sums (CUSUMQ) of the $95 \%$ probability limits, we determine the violation of the probability limits, which induce that series have an unstable behaviour. Figure 2 illustrates the results obtained from the CUSUMQ test for the financial markets' profitability.

Figure 2: CUSUMQ test for the financial markets' profitability in the full period
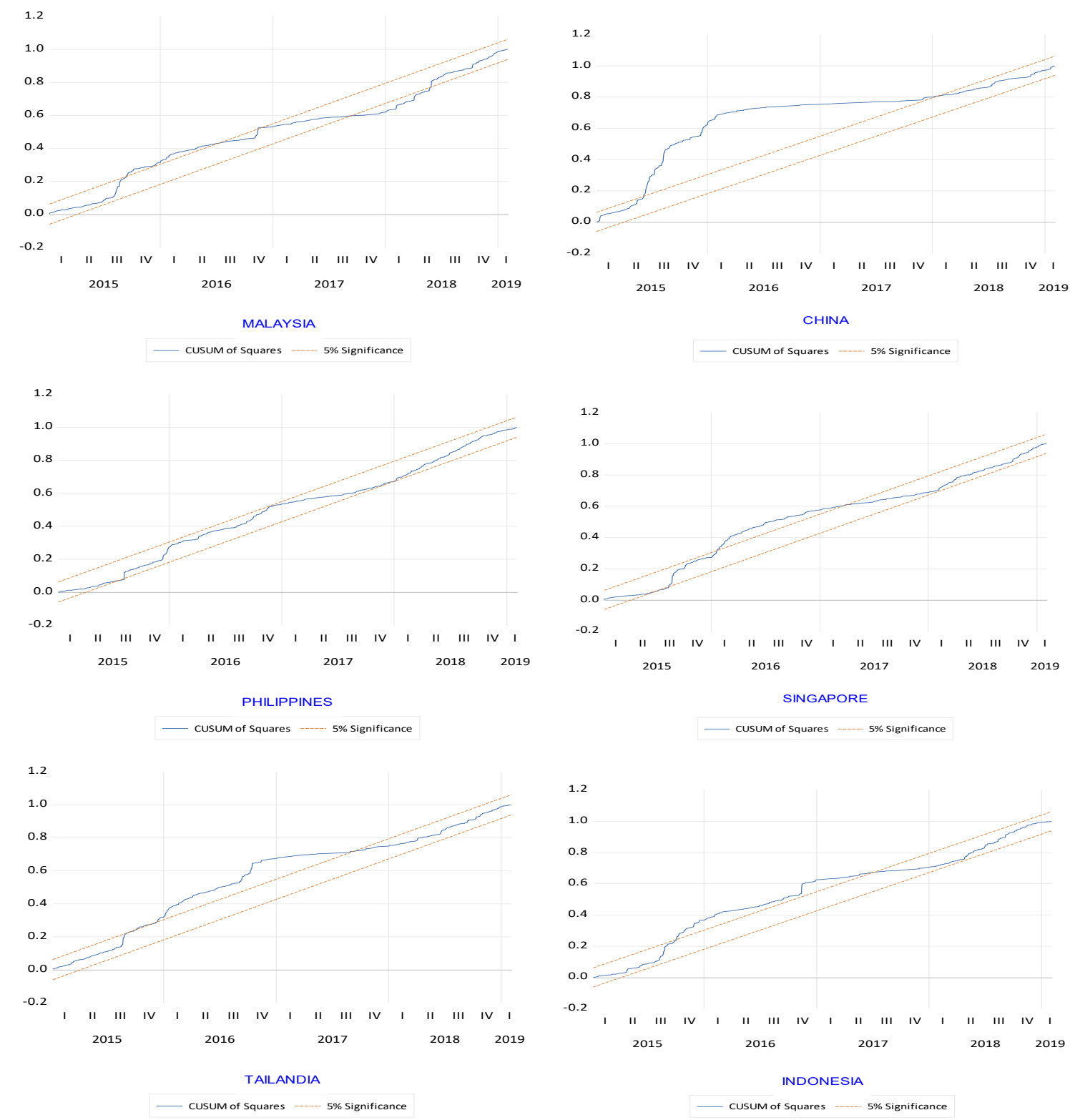

Source: Authors. 
As for the test of Clemente, Montañés and Reyes (1998) represented by Figure 3, it identified the most significant structural breaks in the period from January 2015 to January 2019, showing the turbulence experienced in these markets in the period of China stock market crash, in 2015. The Chinese market crashed in August 2015, the Philippines, Singapore and Thailand followed the same trend. However, the financial markets of Indonesia and Malaysia show the most significant breaks in structure in the years 2016 and 2018, respectively.

Figure 3: Structural breaks through Clemente, Montañés and Reyes (1998), test (full period)
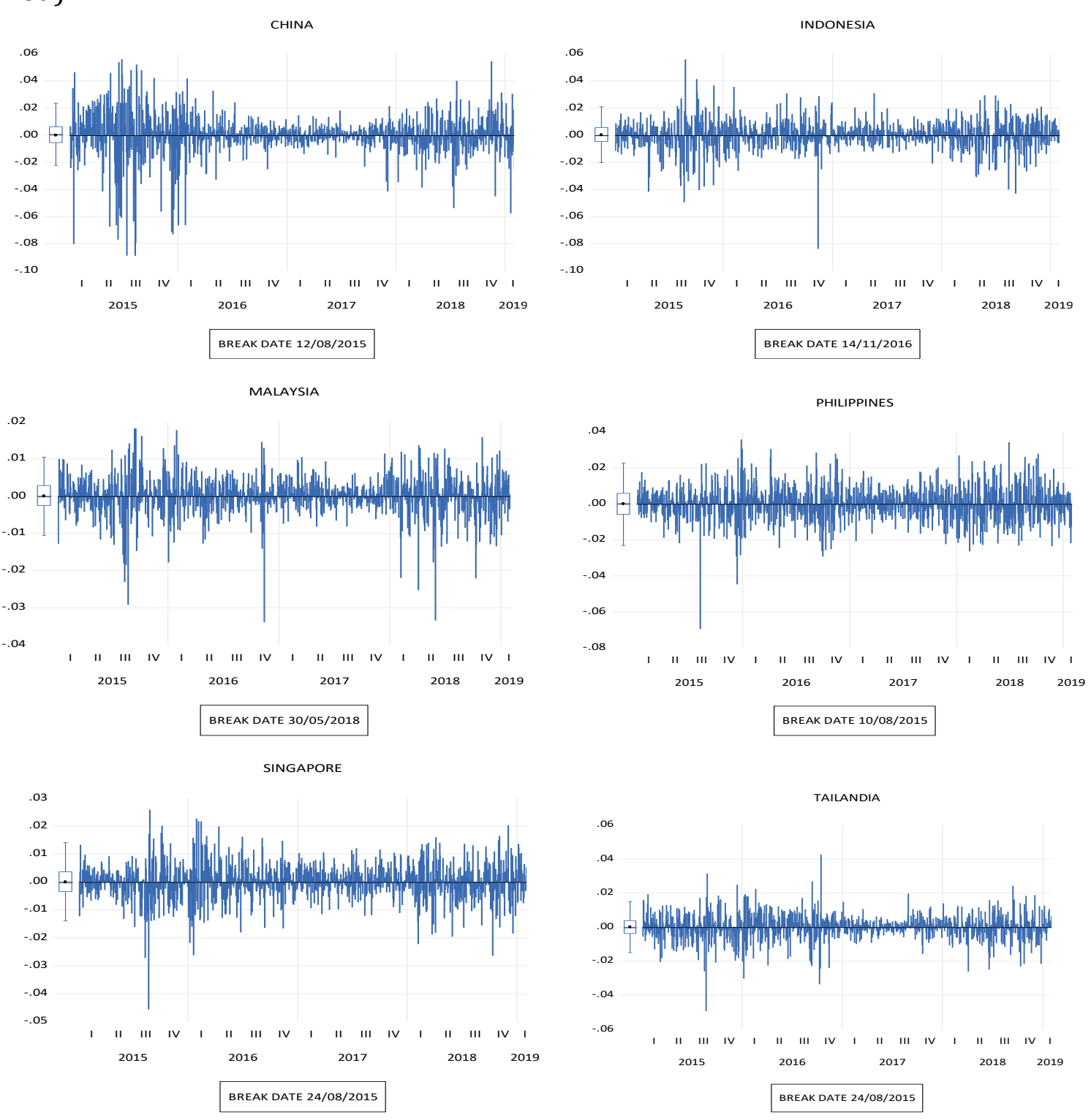

Source: Authors.

\section{Financial Integration}

Table 2 shows the results of the integration tests between the ASEAN-5 and China markets, in the 2015 pre-crash subperiod. The markets that integrated were the pairs, Malaysia/Singapore and China/Philippines, with structural breaks in 2015, i.e. in 30 
possible combinations there was only integration in three cases. These results are in line with the evidence suggested by Teulon, Guesmi and Mankai (2014), who argue that these markets are segmented. However, when compared with the results suggested by Boubakri and Guillaumin (2015), Pradhan et al. (2016), Gulzar et al. (2019), the results are partially contrary, because these markets are segmented rather than integrated.

Tab. 2: Financial integration with structural breaks by Gregory and Hansen (1996) in the pre-crash subperiod

\begin{tabular}{|l|c|c|c|c|c|}
\hline \multicolumn{1}{|c|}{ Markets } & t-statistic & Method & Lags & Break Date & Results \\
\hline $\begin{array}{l}\text { MALAYSIA } \\
\text { SINGAPORE }\end{array}$ & $-5,25^{* *}$ & Trend & 3 & $12 / 02 / 2015$ & Cointegration \\
\hline $\begin{array}{l}\text { SINGAPORE } \\
\text { MALAYSIA }\end{array}$ & $-5,25^{* *}$ & Trend & 5 & $22 / 03 / 2015$ & Cointegration \\
\hline $\begin{array}{l}\text { CHINA } \\
\text { PHILIPPINES }\end{array}$ & $-5,16^{* *}$ & Regime & 1 & $03 / 04 / 2015$ & Cointegration \\
\hline
\end{tabular}

Notes: Data analysis using software STATA. The AIC information criterion was chosen. The critical values for the ADF and Zt parameters are: $-5,45(1 \%) ;-4,99(5 \%) ;-4,72$ $(10 \%)$. For the Za parameter, the critical values are: $-57,28(1 \%) ;-47,96(5 \%) ;-43,22$ $(10 \%)$. The asterisks $* * *, * *, *$ indicate statistical significance at $1 \%, 5 \%$ and $10 \%$, respectively.

Source: Own elaboration.

The results of the integration tests between the markets, in the 2015 sub-period of the stock market crash are shown in Table 3. The results show 16 pairs of integrated markets with structural breaks (in 30 possible). 
Tab. 3: Financial integration with structural breaks by Gregory and Hansen (1996) in the crash subperiod

\begin{tabular}{|l|c|c|c|c|c|}
\hline \multicolumn{1}{|c|}{ Markets } & $\begin{array}{c}\text { t- } \\
\text { statistic }\end{array}$ & Method & Lags & Break Date & Results \\
\hline INDONESIA / MALAYSIA & $-5.90^{* * *}$ & Trend & 1 & $10 / 09 / 2015$ & Cointegration \\
\hline INDONESIA / PHILIPPINES & $-4.96^{*}$ & Trend & 1 & $12 / 08 / 2015$ & Cointegration \\
\hline INDONESIA / SINGAPORE & $-5.99^{* * *}$ & Regime & 1 & $06 / 10 / 2015$ & Cointegration \\
\hline INDONESIA / THAILAND & $-5.20^{* *}$ & Trend & 1 & $12 / 08 / 2015$ & Cointegration \\
\hline INDONESIA / CHINA & $-5.20^{* *}$ & Trend & 1 & $12 / 08 / 2015$ & Cointegration \\
\hline MALAYSIA / INDONESIA & $-5.50^{* * *}$ & Trend & 1 & $10 / 09 / 2015$ & Cointegration \\
\hline MALAYSIA / PHILIPPINES & $-5.08^{* *}$ & Regime & 5 & $24 / 09 / 2015$ & Cointegration \\
\hline MALAYSIA / SINGAPORE & $-4.89^{*}$ & Regime & 3 & $21 / 092015$ & Cointegration \\
\hline MALAYSIA / CHINA & $-5.13^{* *}$ & Regime & 5 & $07 / 10 / 2015$ & Cointegration \\
\hline PHILIPPINES / SINGAPORE & $-4.74^{*}$ & Regime & 0 & $08 / 12 / 2015$ & Cointegration \\
\hline THAILAND / CHINA & -4.88 & Trend & 5 & $20 / 11 / 2015$ & Cointegration \\
\hline CHINA / INDONESIA & $-5.92^{* * *}$ & Regime & 4 & $18 / 12 / 2015$ & Cointegration \\
\hline CHINA / MALAYSIA & $-6.07^{* * *}$ & Regime & 4 & $18 / 12 / 2015$ & Cointegration \\
\hline CHINA / PHILIPPINES & -4.86 & Trend & 5 & $09 / 10 / 2015$ & Cointegration \\
\hline CHINA / SINGAPORE & $-5,95^{* * *}$ & Trend & 4 & $15 / 12 / 2015$ & Cointegration \\
\hline CHINA / THAILAND & $-5,14^{* *}$ & Trend & 5 & $13 / 08 / 2015$ & Cointegration \\
\hline
\end{tabular}

Notes: Data analysis using software STATA. The AIC information criterion was chosen. The critical values for the ADF and Zt parameters are: $-5,45(1 \%) ;-4,99(5 \%) ;-4,72$ $(10 \%)$. For the Za parameter, the critical values are: $-57,28(1 \%) ;-47,96(5 \%) ;-43,22$ $(10 \%)$. The asterisks $* * *, * *, *$ indicate statistical significance at $1 \%, 5 \%$ and $10 \%$, respectively.

Source: Authors.

Evidence show that the Indonesian and Chinese markets are the most integrated stock market indices with their pairs, 5 integration (out of 5 possible). Malaysia, the Philippines and Thailand have 4 and 1 integration respectively. Structural breaks are synchronized between August and December 2015, showing the impact of China's stock market crash, on these regional markets. When compared with the previous sub-period, we found that during the stock market crash the level of financial integration (number of integrated markets) increased by 533\%. These results give support to our first research question. The evidence are in line with the results presented by Glick and Hutchison (2013), Auer and Mehrotra (2014), Boubakri and Guillaumin (2015), Pradhan et al. (2016), Wu (2019), Gulzar et al. (2019), which show that these markets tend to integrate in turbulent periods. In addition, these results should be relevant for public policies related to regional financial integration, which may reduce the benefit of regional diversification strategies, and expose countries in the region to an increased contagion risk.

As for Table 4, it shows the results of financial integration analysis in the post-crash subperiod. Evidence shows the existence of 8 pairs of integrated markets with structural 
breaks (in 30 possible). Indonesia and China are the indexes that most integrated with their pairs, 3 integrations (out of 5 possible). While Thailand and Singapore have a single integration with other markets. As for Malaysia and Philippines, these markets did not integrate with their regional peers, while the structural breaks occur mostly in the year 2018. When compared with the crash subperiod, the level of integration (number of integrated markets) decreases by $50 \%$. This evidence is also of interest to policy makers and investors in relation to the development of regional policies and portfolio diversification strategies in the ASEAN-5 region. These results are in line with findings obtained by Pradhan et al. (2016) and Wu (2019).

Tab. 4: Financial integration with structural breaks by Gregory and Hansen (1996) in the post-crash subperiod

\begin{tabular}{|l|c|c|c|c|c|}
\hline \multicolumn{1}{|c|}{ Markets } & $\begin{array}{c}\text { t- } \\
\text { statistic }\end{array}$ & Method & Lags & Break Date & Results \\
\hline INDONESIA / PHILIPPINES & $-5.07^{* *}$ & Trend & 0 & $27 / 04 / 2018$ & Cointegration \\
\hline INDONESIA / THAILAND & $-44,44^{*}$ & Regime & 0 & $06 / 08 / 2018$ & Cointegration \\
\hline INDONESIA / CHINA & $-5.16^{* *}$ & Regime & 1 & $07 / 12 / 2017$ & Cointegration \\
\hline SINGAPORE / MALAYSIA & $-5.34^{* *}$ & Trend & 5 & $06 / 07 / 2018$ & Cointegration \\
\hline TAILANDIA/ INDONESIA & $-4.89^{*}$ & Regime & 0 & $04 / 07 / 2018$ & Cointegration \\
\hline CHINA / INDONESIA & $-5.50^{* * *}$ & Regime & 3 & $02 / 01 / 2018$ & Cointegration \\
\hline CHINA / MALAYSIA & $-4.76^{*}$ & Trend & 3 & $28 / 03 / 2018$ & Cointegration \\
\hline CHINA / THAILAND & $-4.93^{*}$ & Trend & 3 & $29 / 03 / 2018$ & Cointegration \\
\hline
\end{tabular}

Notes: Data worked on by the authors (software: Stata). The AIC information criterion was chosen. The critical values are found in Gregory and Hansen (1996). The critical values for the ADF and Zt parameters are: $-5,45(1 \%) ;-4,99(5 \%) ;-4,72(10 \%)$. For the $\mathrm{Za}$ parameter, the critical values are: $-57,28(1 \%) ;-47,96(5 \%) ;-43,22(10 \%)$. The asterisks $* * *, * *, *$ indicate statistical significance at $1 \%, 5 \%$ and $10 \%$, respectively. Source: Authors.

\section{Co-movements between markets}

Granger's causality test helps to understand the linkages between markets, but does not allow us to understand whether the financial markets profitability produce a negative or a positive effect on their peers, nor does it allow us to know whether some links are stronger than others. To this end, we use the generalized impulse-response functions, of a magnitude corresponding to a standard deviation, in order to obtain additional evidence on the short-term co-movements between the ASEAN-5 financial markets and the Chinese market. The results of the impulse response functions, with Monte Carlo simulations, applied to the financial market profitability, in the three sub-periods.

Results of the impulse response functions, calculated based on the autoregressive vector model, in the pre-crash subperiod show that Malaysia is the market that originates the majority of the shocks (29), causing a higher number of reactions in the Indonesian and Singapore markets, 8 and 7 shocks respectively (out of 10 possible). Indonesia, Thailand, 
causes 26, 25 reactions, respectively, while Singapore, Philippines and China originated 24,23 shocks in their pairs. Indonesia and Singapore markets absorbed more shocks from their peers, with 32 and 28 shocks, respectively.

Most of the observed shocks resulted in statistically significant effects for more than one period. Nine shocks had statistically significant effects for only one period (10 days), namely the impulses caused by the Indonesian market in the Chinese market, which raises some surprise. These results are not in line with some studies, like the ones from Yu, Fung and Tam (2010), Huyghebaert and Wang (2010), which show that the possibility of other markets influencing the Chinese stock market is relatively low because the Chinese market is still isolated from the rest of the world.

In the subperiod representing the 2015 stock market crash, the majority of the relationships between the markets proved to be significant. Thailand is the market that generates the higher number of impulses in its pairs (26), causing significant shocks in the Chinese market ( 7 out of 10 possible). The Singapore, Philippines and Malaysia markets caused 23, 22, 21 shocks in their peers, in comparison, while the China and Indonesia markets caused 18 shocks in their peers. The market that absorbed the higher number of shocks from its peers, was the Chinese market (37), receiving 9 shocks (out of 10 possible) only from the markets of Malaysia and Philippines. These results, clearly shows that the Chinese market suffered very significant shocks during the crash subperiod, which is an evidence of significant levels of arbitrage and may jeopardize market efficiency, in its weak form.

However, in the crisis subperiod, most markets decreased the co-movements with their regional peers, with the exception of Thailand. Compared to the pre-crash subperiod the shocks decreased significantly, from 151 to 128 . These results reject the second research question and contrary to the evidence showed in Boubakri and Guillaumin (2015), Pyun and An (2016), Virk and Javed (2017) and Gulzar et al. (2019), who advocate that financial integration promote short-term co-movements among financial markets.

As for the post-crash subperiod, the impulses were, in general, statistically significant with the identification of 150 reactions between the markets. Singapore financial market caused the majority of shocks in its peers (28), with higher relevance in Indonesia and Thailand ( 7 out of 10 possible). In comparison, the markets of Indonesia, China and Thailand caused 26, 25 shocks in their pairs. Indonesia and Philippines markets caused the lowest reaction in their pairs, with 24 and 22 shocks, respectively. Malaysia and Indonesia markets were the most affected, respectively, with 27 and 26 shocks. The ASEAN-5 financial markets increased their co-movements in the post-crash period. However, the Thai market decreased its co-movements with its peers, but with little significance.

The number of statistically significant shocks in the three sub-periods was of 151 (precrash), 128 (crash) and 150 (post-crash), which lead to the conclusion that the 2015 stock market crash caused a decrease in co-movements between the financial markets of the ASEAN-5 Region and China. These evidence are in line with Azad (2009) showing that the 
Chinese stock market presents some predictability, and in opposition to the results of Auer and Mehrotra (2014), Pyun and An (2016), Virk and Javed (2017) and Gulzar et al. (2019). These authors defended that the increase in financial integration promotes shortterm co-movements among financial markets.

\section{Conclusion}

In this study, we investigate financial integration and short-term co-movements between the financial markets of Indonesia, Malaysia, Philippines, Singapore and Thailand (ASEAN-5), and the market of China, during China stock market crash in 2015. The overall objective of this research was to estimate potential portfolio diversification in these regional financial markets. The sample period comprises the time span from January 2015 to January 2019, and has been broken down into three sub-periods. We conducted two main statistical tests for this purpose. The first test estimates whether the markets show significant levels of financial integration, resulting from the stock market crash in China. The second assesses whether the price indices exhibit co-movements, showing reversion to the average, that is, whether the hypothesis of arbitrage and anomalous profitability are feasible.

As for the issue of integration, the results show 3 pairs of integrated markets with structural breaks in the pre-crash subperiod, i.e. these markets are segmented and not integrated. In the 2015 stock market crash subperiod, the results suggest 16 pairs of integrated markets, with structural breaks (out of 30 possible). We found that the structural breaks are synchronized between August and December 2015, showing the impact of the crash in these regional markets. When compared with the previous subperiod we found that during the stock market crash the level of financial integration rose $533 \%$. In the post-crash, only 8 markets show to be integrated with their peers, with structural breaks. Thus, the level of integration decreased by $50 \%$, when compared to crash subperiod. This evidence confirm our first research question and it is relevant for policy makers and investors, regarding the development of regional policies and portfolio diversification strategies in the ASEAN-5 region.

The second set of tests shows that during the 2015 stock market crash, the majority of the financial markets decreased the co-movements with their regional peers, with the exception of Thailand's market. The number of statistically significant shocks in the three sub-periods was 151, 128 and 150, respectively, which indicates that the 2015 stock market crash decreased the co-movements between markets in the ASEAN-5 region and China, which were higher in non-crisis subperiods. Additionally, the impulse response functions showed positive co-movements, with statistical significance and persistence exceeding one week. Thus, evidence shows that the assumption of market efficiency is questionable, since the forecast of market movements may be improved, if the lagged movements of the remaining markets are taken into account, allowing the occurrence of arbitrage operations. Therefore, it is beneficial for international investors to diversify their portfolios in these regional markets. 
Overall, the study demonstrates, sustained by evidence obtained in the econometric models, that China stock market crash, in 2015, had a significant impact on the memory properties of the financial market indices of ASEAN-5 and China. Due to the significantly decreased of financial integration, in the post-crash period, the implementation of portfolio diversification strategies may be achieved. In conclusion, the ASEAN-5 and China markets may not be efficient in their weak form due to the high levels of arbitrage identified. However, we believe that implementing efficient portfolio diversification strategies, based on historical prices, is still beneficial for investors. These conclusions also contribute to robust market regulators knowledge in order for them to take measures that reduce information asymmetry between these markets and other international markets.

\section{References}

1. ABDULLAH M. N., M. Z. RAHMAN, 2010. Stationarity of South Asian Real Exchange Rates Under Exponential Star (ESTAR) Framework. The Journal of Developing Areas. 43(2), 41-50. doi: 10.1353/jda.0.0068.

2. AHMED, A. D., R. HUO, 2019. Impacts of China's crash on Asia-Pacific financial integration: Volatility interdependence, information transmission and market comovement. Economic Modelling. 79, 28-46. doi: 10.1016/j.econmod.2018.09.029.

3. AUER, R. A., A. MEHROTRA, 2014. Trade linkages and the globalisation of inflation in Asia and the Pacific. Journal of International Money and Finance. 49(PA), 129151. doi: 10.1016/j.jimonfin.2014.05.008.

4. AZAD, A. S. M. S., 2009. Random walk and efficiency tests in the Asia-Pacific foreign exchange markets: Evidence from the post-Asian currency crisis data. Research in International Business and Finance. 23(1), 322-338. doi: 10.1016/j.ribaf.2008.11.001.

5. AZMAN-SAINI, W. N. W. et al., 2002. Financial integration and the ASEAN-5 equity markets. Applied Economics. 34(18), 2283-2288. doi: 10.1080/00036840210139364.

6. BOUBAKRI, S., C. GUILLAUMIN, 2015. Regional integration of the East Asian stock markets: An empirical assessment, Journal of International Money and Finance. 57(C), 136-160. doi: 10.1016/j.jimonfin.2015.07.011.

7. BURDEKIN, R. C. K., P. L. SIKLOS, 2012. Enter the dragon: Interactions between Chinese, US and Asia-Pacific equity markets, 1995-2010. Pacific Basin Finance Journal. 20(3), 521-541. doi: 10.1016/j.pacfin.2011.12.004.

8. CAPORALE, G. M. et al. 2013. Volatility spillovers and contagion from mature to emerging stock markets. Review of International Economics. 21(5), 1060-1075. doi: 10.1111/roie.12091.

9. CHACHAVAlPONGPUN, P., 2018. How Does the United States Play into the East Asia Summit for ASEAN? ASEAN-U.S. Relations. doi: 10.1355/9789814311762009.

10. CHEN, C. W. S. et al., 2009. The impact of structural breaks on the integration of the 
ASEAN-5 stock markets. Mathematics and Computers in Simulation. 79(8), 26542664. doi: 10.1016/j.matcom.2008.12.012.

11. CLEMENTE, J., A. MONTAÑÉS, M. REYES, 1998. Testing for a unit root in variables with a double change in the mean. Economics Letters. 59(2). 175-182. doi: 10.1016/S0165-1765(98)00052-4.

12. COEURDACIER, N., S. GUIBAUD, 2011. International portfolio diversification is better than you think. Journal of International Money and Finance. doi: 10.1016/j.jimonfin.2010.10.003.

13. DIAS, R., J. V. DA SILVA, A. DIONÍSIO, 2019. Financial markets of the LAC region: Does the crisis influence the financial integration?. International Review of Financial Analysis. 63(February), 160-173. doi: 10.1016/j.irfa.2019.02.008.

14. DICKEY, D., W. FULLER, 1981. Likelihood ratio statistics for autoregressive time series with a unit root. Econometrica. 49(4), 1057-1072. doi: 10.2307/1912517.

15. ENGLE, R. F., C. W. J. GRANGER, 1987. Co-Integration and Error Correction: Representation, Estimation, and Testing. Econometrica. 55(2), 251. doi: $10.2307 / 1913236$.

16. FORBES, K. J., R. RIGOBON, 2002. No contagion, only interdependence: Measuring stock market comovements. Journal of Finance. 57(5), 2223-2261. doi: 10.1111/0022-1082.00494.

17. GLICK, R., M. HUTCHISON, 2013. China's financial linkages with Asia and the global financial crisis. Journal of International Money and Finance. 39(C), 186-206. doi: 10.1016/j.jimonfin.2013.06.025.

18. GREGORY, A. W., B. E. HANSEN, 1996. Residual-based tests for cointegration in models with regime shifts. Journal of Econometrics. 70(1), 99-126. doi: 10.1016/0304-4076(69)41685-7.

19. GULZAR, S. et al., 2019. Financial cointegration and spillover effect of global financial crisis: a study of emerging Asian financial markets. 32(1), 187-218. Economic Research-Ekonomska Istrazivanja. doi: 10.1080/1331677X.2018.1550001.

20. HUYGHEBAERT, N., L. WANG, 2010. The co-movement of stock markets in East Asia. Did the 1997-1998 Asian financial crisis really strengthen stock market integration?. China Economic Review. 21(1), 98-112. doi: 10.1016/j.chieco.2009.11.001.

21. INCLÁN, C., G. C. TIAO, 1994. Use of cumulative sums of squares for retrospective detection of changes of variance. Journal of the American Statistical Association. 89(427), 913-923. doi: 10.1080/01621459.1994.10476824.

22. JAKPAR, S. et al., 2013. An Econometric Analysis on the Co-Movement of Stock Market Volatility between China and ASEAN-5. International Journal of Business and Social Science.

23. JARQUE, C. M., A. K. BERA, 1980. Efficient tests for normality, homoscedasticity and serial independence of regression residuals. Economics Letters. 6(3), 255-259. doi: 10.1016/0165-1765(80)90024-5.

24. JOHANSEN, S., 1988. Statistical Analysis of Cointegrated Vectors. Journal of 
Economic Dynamics and Control. 12(2-3), 231-254.

25. KWIATKOWSKI, D. et al., 1992. Testing the null hypothesis of stationary against the alternative of a unit root. Journal of econometrics. 54(1), 159-178. doi: http://dx.doi.org/10.1016/0304-4076(92)90104-Y.

26. LÜTKEPOHL, H., P. SAIKKONEN, 1997. Impulse response analysis in infinite order cointegrated vector autoregressive processes. Journal of Econometrics. 81(1), 127157. doi: 10.1016/S0304-4076(97)00037-7.

27. MADDALA, G. S., I.-M. KIM, 1998. Unit roots, cointegration, and structural change. Cambridge University Press. Available from: http://search.ebscohost.com/login.aspx?direct=true\&site=edslive\&db=edszbw\&AN=EDSZBW24264628X (Accessed: 15 September 2017).

28. MCKINNON, R., G. SCHNABL, 2003. Synchronised Business Cycles in East Asia and Fluctuations in the Yen/Dollar Exchange Rate. The World Economy. 26(8), $1067-$ 1088. doi: 10.1111/1467-9701.00563.

29. PETRI, P. A., M. G. PLUMMER, F. ZHAI, 2012. ASEAN Economic Community: A General Equilibrium. Analysis. Asian Economic Journal. 26(2), 93-118. doi: 10.1111/j.1467-8381.2012.02079.x.

30. PHILliPS, P. C. B., P. PERRON, 1988. Testing for a unit root in time series regression. Biometrika. 75(2), 335-346. doi: 10.1093/biomet/75.2.335.

31. POWNALL, R. A. J., S. SATCHELL, N. SRIVASTAVA, 2019. A random walk through Mayfair: Art as a luxury good and evidence from dynamic models. Journal of International Money and Finance. 95, 112-127. doi: 10.1016/j.jimonfin.2019.04.001.

32. PRADHAN, R. P. et al., 2016. Insurance penetration and economic growth nexus: Cross-country evidence from ASEAN. Research in International Business and Finance. 36, 447-458. doi: 10.1016/j.ribaf.2015.09.036.

33. PYUN, J. H., J. AN, 2016. Capital and credit market integration and real economic contagion during the global financial crisis. Journal of International Money and Finance. 67(C), 172-193. doi: 10.1016/j.jimonfin.2016.04.004.

34. SALIDJANOVA, N., I. KOCH-WESER, 2015. China 's Economic Ties with ASEAN : A Country-by-Country Analysis, U.S.-China Economic and Securirty Review Commission, Staff Research Report.

35. TEULON, F., K .GUESMI, S. MANKAI, 2014. Regional stock market integration in Singapore: A multivariate analysis. Economic Modelling. 43, 217-224. doi: 10.1016/j.econmod.2014.07.045.

36. VIRK, N., F. JAVED, 2017. European equity market integration and joint relationship of conditional volatility and correlations. Journal of International Money and Finance. 71(C), 53-77. doi: 10.1016/j.jimonfin.2016.10.007.

37. WANG, K., Y. H. CHEN, S. W. HUANG, 2011. The dynamic dependence between the Chinese market and other international stock markets: A time-varying copula approach. International Review of Economics and Finance. 20(4), 654-664. doi: 10.1016/j.iref.2010.12.003.

38. WONG, D. K. T., LI, K. W., 2010. Comparing the performance of relative stock return 
differential and real exchange rate in two financial crises. Applied Financial Economics. 20(1-2), 137-150. doi: 10.1080/09603100903266468.

39. WU, F., 2019. Stock market integration in East and Southeast Asia: The role of global factors. International Review of Financial Analysis. 67. doi: 10.1016/j.irfa.2019.101416.

40. YU, I. W., K. P. FUNG, C. S. TAM, 2010. Assessing financial market integration in Asia

- Equity markets. Journal of Banking and Finance. 34(12), 2874-2885. doi: 10.1016/j.jbankfin.2010.02.010.

41. ZIVOT, E., ANDREWS, D. W. K., 1992. Further Evidence on the Great Crash, the Oil Price Shock, and the Unit Root Hypothesis. Journal of Business \& Economic Statistics. 10(3), 251-270. doi: 10.1198/073500102753410372.

\section{Contact address of the authors:}

Rui Dias, Polytechnic Institute of Setúbal, School of Business and Administration, ESCE, Campus do Instituto Politécnico de Setúbal, Estefanilha, 2914-503 Setúbal, Portugal, email: rui.dias@esce.ips.pt

Pedro Pardal, Ph.D., Department of Accounting and Finance, Business and Management School, Polytechnic Institute of Setúbal, Campus do IPS - Estefanilha - 2910-761 Setúbal, Portugal, e-mail: pedro.pardal@esce.ips.pt

Nuno Teixeira, Ph.D., Department of Accounting and Finance, Business and Management School, Polytechnic Institute of Setúbal, Campus do IPS - Estefanilha - 2910-761 Setúbal, Portugal, e-mail: nuno.teixeira@esce.ips.pt

Ing. Veronika Machová, MBA, School of Expertness and Valuation, Institute of Technology and Business in České Budějovice, Okružní 517/10, 37001 České Budějovice, Czech Republic, e-mail: machova@mail.vstecb.cz 